\title{
Functional morphology of the cranio-mandibular complex of the Guira cuckoo (Aves)
}

\author{
Sofía Pestoni1,2 (1) | Federico Javier Degrange2,3 | Claudia Patricia Tambussi2,3 | \\ María Manuela Demmel Ferreira ${ }^{4}$ | Germán Alfredo Tirao ${ }^{2,5}$
}

${ }^{1}$ Instituto Multidisciplinario de Biología Vegetal (IMBIV), CONICET-UNC, Córdoba, Argentina

${ }^{2}$ Consejo Nacional de Investigaciones Científicas y Técnicas (CONICET), Buenos Aires, Argentina

${ }^{3}$ Centro de Investigaciones en Ciencias de la Tierra (CICTERRA), UNC-CONICET,

Córdoba, Argentina

${ }^{4}$ Facultad de Ciencias Exactas, Físicas y Naturales (FCEFyN), Universidad Nacional de Córdoba, Córdoba, Argentina

${ }^{5}$ Instituto de Física Enrique Gaviola (IFEG), CONICET-UNC, Córdoba, Argentina

\section{Correspondence}

Sofía Pestoni, Edificio de Investigaciones Biológicas y Tecnológicas (western wing), Av. Velez Sarsfield 1611. Ciudad Universitaria, Postal box: 495, Córdoba 5000, Argentina.

Email: sofipestoni@gmail.com

\section{Funding information}

Consejo Nacional de Investigaciones Científicas y Técnicas, Grant/Award number: PICT2014-2330, PIP2014-0059, and PUE-2016

\begin{abstract}
The cranio-mandibular complex is an important structure involved in food capture and processing. Its morphology is related to the nature of the food item. Jaw muscles enable the motion of this complex and their study is essential for functional and evolutionary analysis. The present study compares available behavioral and dietary data obtained from the literature with novel results from functional morphological analyses of the cranio-mandibular complex of the Guira cuckoo (Guira guira) to understand its relationship with the zoophagous trophic habit of this species. The bite force was estimated based on muscle dissections, measurements of the physiological crosssectional area, and biomechanical modeling of the skull. The results were compared with the available functional morphological data for other birds. The standardized bite force of G. guira is higher than predicted for exclusively zoophagous birds, but lower than for granivorous and/or omnivorous birds. Guira guira possesses the generalized jaw muscular system of neognathous birds, but some features can be related to its trophic habit. The external adductor muscles act mainly during food item processing and multiple aspects of this muscle group are interpreted to increase bite force, that is, their high values of muscle mass, their mechanical advantage (MA), and their perpendicular orientation when the beak is closed. The $m$. depressor mandibulae and the $m$. pterygoideus dorsalis et ventralis are interpreted to prioritize speed of action (low MA values), being most important during prey capture. The supposed ecological significance of these traits is the potential to widen the range of prey size that can be processed and the possibility of rapidly capturing agile prey through changes in the leverage of the muscles involved in opening and closing of the bill. This contributes to the trophic versatility of the species and its ability to thrive in different habitats, including urban areas.
\end{abstract}

\section{KEYWORDS}

bite force, Cuculiformes, ecomorphology, Guira guira, mandibular muscles

\section{1 | INTRODUCTION}

Organisms can be considered to be the result of processes explained by phylogenetic relationship, adaptation, ontogenic, and constructional limitations (Briggs, 2005; Seilacher, 1991). Knowledge of how the structural components of an organism are arranged and function in the environment is fundamental to understanding their development, function, adaptation, and evolution. The cranio-mandibular complex in birds represents an excellent system to explore such a theme. Because the bill is the main structure for acquisition and preliminary processing of food (Korzun, Erard, Gasc, \& Dzerzhinsky, 2008), favoring either force or velocity depending on the trophic habit of the species (Corbin, Lowenberger, \& Gray, 2014; Herrel, O'Reilly, \& Richmond, 2002; Reiser, Welch, Suarez, \& Altshuler, 2013; Ritchie, 1954; Vogel, 2013), the morphology of the beak and the cranio-mandibular complex are likely to be subject to selective pressure (Clabaut, Herrel, Sanger, Smith, \& Abzhanov, 2009; Korzun, Erard, Gasc, \& Dzerzhinsky, 2003).

Among birds, functional morphological studies are more abundant on highly specialized species or in those with striking morphological features (e.g., Carril, Degrange, \& Tambussi, 2015; Herrel, Podos, 
Huber, \& Hendry, 2005; Herrel, Podos, Vanhooydonck, \& Hendry, 2009; Korzun, Erard, \& Gasc, 2001; Korzun et al., 2008; Soons et al., 2015; Van der Meij \& Bout, 2004, 2006, 2008). However, it is necessary to also generate baseline data of a wider range of species, including generalist or opportunist species in order to understand why these species are, for example, capable of conquering diverse habitats and, on a much larger scale, to understand the diversity of trophic systems and the evolution of birds (Bhattacharyya, 2013).

Although cuculiform diversity is appreciated in many aspects of their biology (e.g., parasitism, migration, terrestrial and arboreal habits, phylogenetic relationships), many other aspects remain to be investigated. Specifically in Cuculidae, few studies of the musculo-skeletal system are restricted to a small number of species. In the last century, some morphological studies were carried out in order to elucidate the phylogenetic relationship of Cuculiformes with Musophagidae (Bannerman, 1933; Berger, 1960; Lowe, 1943; Shufeldt, 1901; Verheyen, 1956; Zinoviev, 2007), a taxon considered to be close to Cuculiformes along with the hoatzin Opisthocomus hoazin. Pycraft (1903) studied the cranium of several members of Cuculiformes, but Hughes (2000) pointed out the necessity of additional morphological studies. In line with that, Posso and Donatelli $(2001,2005)$ presented a broad and accurate description of the skulls of the cuculid subfamily Crotophaginae (three Crotophaga species and the only species of genus Guira). In particular, myological studies are rare and focus on non-cranial musculature (Beddard, 1885; Berger, 1952). Marceliano (1996) developed a detailed description of the cranio-mandibular complex of $O$. hoazin and compared it with some species of Cuculiformes and Musophagiformes, but the descriptions did not follow a modern nomenclature and were not detailed with regards to these two orders. Korzun et al. (2003) published a biomechanical analysis of some species of Opisthocomidae, Musophagidae, and Cuculidae along with a general description and illustrations of the superficial head musculature. Cuculidae, the focus of the current study, were represented by only one species: Cuculus canorus. These latter two studies will serve as a comparative basis for our study.

In the present work, we present a functional morphological analysis of the cranio-mandibular complex in Guira guira in order to evaluate the potential relationships between anatomical structures and trophic adaptations. Guira guira is a South American bird that lives in a wide range of habitats, including urban areas (de la Peña, 2016), and whose trophic habit is a source of controversy. Although it is widely accepted that G. guira is zoophagous (Bernal de Pereyra, 1927, 1935; Daguerre, 1922; Payne, 1997), some authors consider the species to be exclusively insectivorous (Goijman \& Zaccagnini, 2008; Legrand, 1934; Leveau \& Leveau, 2004), while others note a predilection for vertebrates such as amphibians, reptiles, and small birds (including eggs) (Beltzer, 1995; Bernal de Pereyra, 1927; Coutinho, Serra, Junior, \& Lima, 2014; Daguerre, 1922; Koski \& Merçon, 2015; Morais, Siqueira, \& Bastos, 2013; Payne, 1997; Repenning, Basso, Rossoni, Krügel, \& Fontana, 2009). Although recent molecular studies suggest an affinity with bustards (Prum et al., 2015), its phylogenetic relationship with other birds is still the subject of discussion (Hughes, 2000; Mayr, Manegold, \& Johansson, 2003; Sibley \& Ahlquist, 1990).
Here, we describe the anatomy of the jaw muscles, characterize them using a biomechanical approach, and calculate the physiological cross-sectional area (PCSA) in G. guira. The PCSA of a muscle is an estimate of the force-generating capacity of a muscle related to its mass, pinnation angle, and muscle fiber length (e.g., Santana, Dumont, \& Davis, 2010; Sustaita \& Hertel, 2010). In addition, the functional morphological findings on the cranio-mandibular system of this species were compared with the available data on diet and general feeding behavior in order to understand the trophic adaptation of G. guira.

\section{2 | MATERIAL AND METHODS}

\section{$2.1 \mid$ Dissected specimens and description}

Osteological descriptions follow Baumel and Witmer (1993), except where noted. A more detailed description and figures can be found in Supporting Information. The myological descriptions follow Holliday and Witmer (2007) for the adductor muscles and Vanden Berge and Zweers (1993) for the rest of the muscles.

Three adult specimens of Guira guira Gmelin, 1788 (Cuculidae, Crotophaginae), were dissected (CIT-O 278, CIT-O 279, and CIT-O 280). After dissection, the material was skeletonized and deposited in the Avian Osteological Collection of the Centro de Investigaciones en Ciencias de la Tierra CICTERRA (CIT-O). The animals were collected from the wild in Deán Funes (Córdoba), Argentina, following the protocols approved by the animal care committee and adhering to the legal requirements of Argentina, and preserved at $-13.4^{\circ} \mathrm{C}$. The muscles of the cranio-mandibular complex were identified and removed from their origin and insertion sites. The description of the muscles proceeds in order of appearance from superficial to deep muscles. Photographs of the muscles (taken with a Nikon Coolpix P100 digital camera) and illustrations of origin and insertion sites accompany the description.

Computed tomography (CT) scans were acquired using noncommercial equipment developed by researchers from Grupo de Espectroscopía Atómica y Nuclear (GEAN) at Facultad de Matemática, Astronomía y Física (FaMAF). In this equipment, the sample is mounted on a goniometric table with an angular resolution of $4 \mathrm{mrad}$, in order to obtain the different projections (two dimensional [2D]-images in which the X-ray beam have a certain direction), while the X-ray source and the detector remain fixed. This equipment allows obtaining conventional 2D-images of objects with an equivalent thickness of approximately $7 \mathrm{~cm}^{2} / \mathrm{g}$ and a field of view of $200 \mathrm{~mm} \times 200 \mathrm{~mm}$. In this article, the images were acquired using a conventional $\mathrm{X}$-ray source with an anode of $\mathrm{W}$, accelerating voltage of $30 \mathrm{kV}$, filters of $\mathrm{Zr}$ and $\mathrm{Al}$ to modulate the beam energy distribution. The creation of threedimensional models is obtained from multiple 2D-images, from different angular positions, and various mathematical methods of reconstruction (Buzug, 2008). CT-data shown in this work, with a voxel size of $194 \mu \mathrm{m}^{3}$, were obtained from 1,600 projections equally distributed in $360^{\circ}$ and using the usual Filtered Backprojection (FBP) reconstruction algorithm, based on the Radon inverse transformation (Buzug, 2008), with a Shepp-Logan filter and spline interpolation. These algorithms were implemented in MATLAB software. 


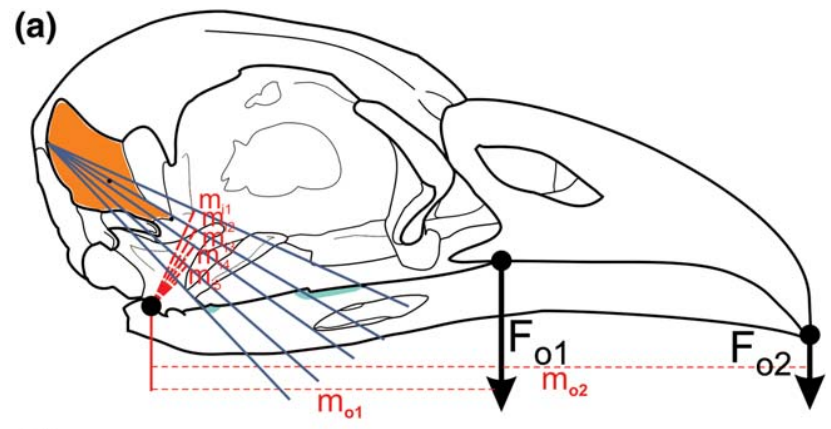

(b)

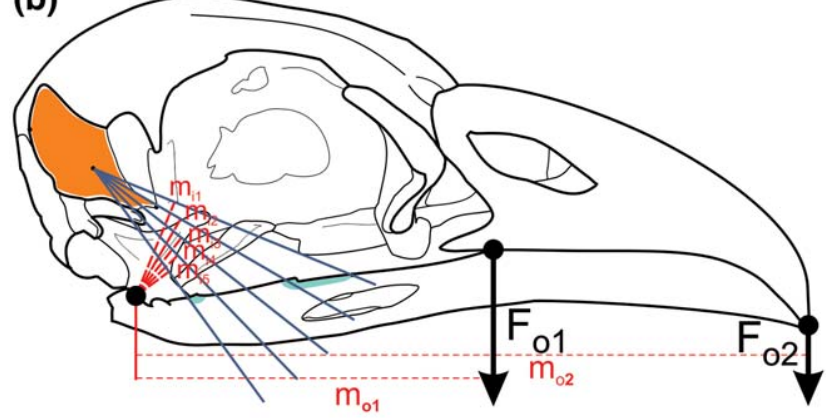

(c)

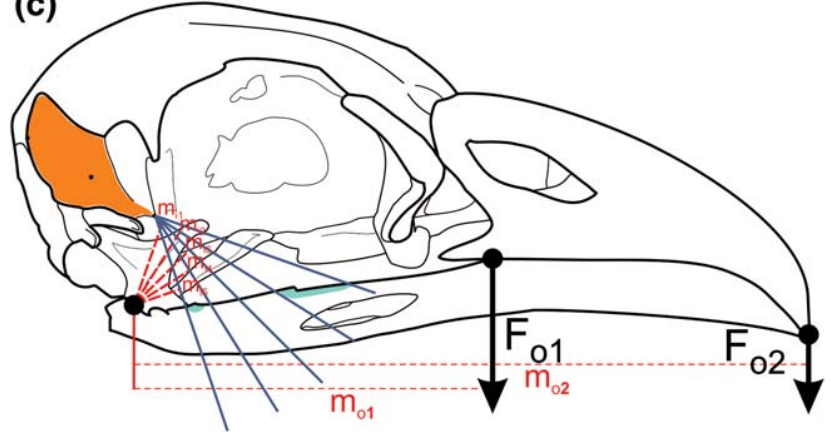

FIGURE 1 Biomechanical modeling of the jaw in Guira guira. The M. adductor mandibulae externus profundus is used as an example. Origin is indicated in the orange area, meanwhile the insertion is represented by the light blue area. Calculation of the in-lever moment arm for the most posterior point (a), for the middle point (b), and for the most anterior point (c) of muscle origin. Abbreviations: $F_{\mathrm{o}}=$ out-force; $m_{\mathrm{i}}=$ in-lever moment arm; $m_{\mathrm{o}}=$ out-lever moment arm. Scale bar $=1 \mathrm{~cm}$

\section{2 | Biomechanical modeling}

Following Sustaita (2008), we used a static two-dimensional biomechanical modeling approach (i.e., no cranial kinesis) to estimate the potential forces the jaw could exert. The jaw was modeled as a simple third-class lever (i.e., with the input force situated between the fulcrum and the output force). In this system, the adductor musculature provides the input force to close the jaw and hold the prey in the bill where the output force is exerted (Figure 1). The quadrato-mandibular joint acts as the pivot of the lever. Since most birds are isognathous (i.e., bite at the same time on both sides; Witmer \& Rose, 1991), the analysis can be applied to each side. The cranio-mandibular joint was considered frictionless and the actions of the ligaments were dismissed (Sustaita, 2008).
The mechanical advantage (MA) of each muscle was calculated as the ratio between in-lever moment arm $\left(m_{\mathrm{i}}\right)$ and out-lever moment arm $\left(m_{0}\right)$ (Hildebrand \& Goslow, 2001). Through MA values, it is possible to establish the relative contributions of force or velocity to the craniomandibular complex when a muscle contracts. The in-lever moment arm is measured as the perpendicular distance between the fulcrum and the lines of action of each jaw muscle, whereas the out-lever moment arm is the straight length from the pivot to the place where the jaw contacts the trophic item. Because the actual lines of action of jaw muscles are often difficult to estimate as they have a large area of origin and/or insertion, we followed the geometric method proposed by Vizcaíno, de luliis, and Bargo (1998) which allows us to obtain a moment arm measurement that takes into account the range of muscle origin and insertion sites. We schematized and digitized origin and insertion sites of each jaw muscle. The center of the origin was calculated by establishing two peripheral points in the muscle origin (the most antero-dorsal and postero-ventral sites) and estimating the midpoint between them (Vizcaíno et al. 1998). One line was drawn between the most anterior part of the insertion and the center of the origin and one line was drawn between the posterior part of the insertion and the center of the origin. The angle between these two lines was subdivided into several lines of action (five in the present study) The moment arms of each line of action were measured and a mean moment arm was calculated. This procedure was repeated with the point of origin changed from the center to the most posterior and most anterior point (Figure 1). From these three mean moment arms (posterior, middle, and anterior), a new mean moment arm is calculated, which represents the moment arm for the studied muscle's line of action. The procedure is then repeated for the rest of the jaw muscles.

\section{$2.3 \mid$ PCSA and estimation of bite force}

The values of PCSA are proportional to the amount of tension a muscle can produce (Bock, 1974; Gans, 1982; Kaufman, An, Litchy, \& Chao, 1991). The PCSA of each muscle was calculated following Sustaita (2008) and according to the equation (Lieber, 2002):

$$
\text { PCSA }\left(\mathrm{mm}^{2}\right)=(m \times \text { cosine } \Theta) /(\rho \times I)
$$

where $m$ is muscle mass (in grams), $\Theta$ is the average angle of pinnation (in degrees), $\rho$ is the density of muscle tissue $\left(1,060 \mathrm{~kg} / \mathrm{m}^{3}\right.$; Pennycuick, 1996), and $I$ is the average fiber length (in millimeters).

Pinnation angles were measured relative to the main axis of the muscle from photographs of isolated muscles and an average was calculated from 16 measures of each muscle. The dissected muscles were then immersed in $15 \% \mathrm{HNO}_{3}$ for $24 \mathrm{hr}$ in order to dissolve the connective tissue that binds the fascicles, separate them, and measure their length (Sustaita, 2008). Average fascicle length was calculated from 10 fibers per muscle. All measurements were taken from digital photographs with a reference grid using ImageJ software (Schneider, Rasband, \& Eliceiri, 2012). Because it is difficult to preserve the integrity of individual muscles during the process of muscle dissection, some measurements could only be taken from two specimens (Table 1). These measurements were used to calculate PCSA, which was then used to 
TABLE 1 Measurements of jaw musculature of Guira guira

\begin{tabular}{|c|c|c|c|c|c|c|c|}
\hline Jaw muscle & $M \pm S E(g)$ & MA & $A\left({ }^{\circ}\right)$ & $\mathrm{FL}(\mathrm{mm})$ & PCSA $\left(\mathrm{mm}^{2}\right)$ & $F_{\mathrm{i}}(\mathrm{N})$ & $F_{o}(\mathrm{~N})$ \\
\hline$d m$ & $0.062 \pm 0.016$ & 0.050 & $9.40 \pm 1.00$ & $9.93 \pm 0.24$ & 5.782 & 1.446 & 0.072 \\
\hline ames & $0.038 \pm 0.017$ & 0.144 & $16.69 \pm 2.56$ & $3.17 \pm 0.39$ & 24.296 & 6.074 & 0.874 \\
\hline amep & $0.090 \pm 0.016$ & 0.205 & $16.11 \pm 4.42$ & $4.15 \pm 0.24$ & 8.494 & 2.123 & 0.435 \\
\hline pss & $0.038 \pm 0.021$ & 0.148 & $18.56 \pm 2.66$ & $2.40 \pm 0.47$ & 12.300 & 3.075 & 0.455 \\
\hline psp & $0.035 \pm 0.004$ & 0.284 & $9.27 \pm 0.97$ & $5.22 \pm 0.43$ & 6.596 & 1.649 & 0.468 \\
\hline$a m p$ & $0.009 \pm 0.004$ & 0.110 & $14.22 \pm 0.08^{a}$ & $3.40 \pm 0.26^{a}$ & 2.676 & 0.669 & 0.074 \\
\hline ptv & $0.111 \pm 0.039$ & 0.084 & $19.86 \pm 9.38$ & $5.98 \pm 0.69$ & 9.122 & 2.280 & 0.191 \\
\hline ptd & $0.056 \pm 0.002$ & 0.095 & $13.20 \pm 1.43^{\mathrm{a}}$ & $4.90 \pm 0.93$ & 24.326 & 6.082 & 0.575 \\
\hline prt & $0.018 \pm 0.004$ & 0.187 & $15.25^{a}$ & $3.43 \pm 0.40^{a}$ & 4.169 & 1.042 & 0.195 \\
\hline
\end{tabular}

Abbreviations: $A=$ angle of pinnation of the fibers; amep $=$ M. adductor mandibulae externus profundus; ames $=$ M. adductor mandibulae externus superficialis; $a m p=M$. adductor mandibulae posterior; $d m=M$. depressor mandibulae; $F_{\mathrm{i}}=$ estimated in-force (Newtons); $F \mathrm{~L}=$ fiber length; $F_{\mathrm{o}}=$ estimated outforce (Newtons); $M=$ muscle mass; $M A=$ mechanical advantage; PCSA = physiological cross sectional area; prt = M. protractor pterygoidei et quadrati; $p s p=$. pseudotemporalis profundus; $p s s=M$. pseudotemporalis superficialis; $p t d=$. pterygoideus dorsalis; $p t v=$. . pterygoideus ventralis ${ }^{a}$ Taken from two specimens.

estimate bite force of $G$. guira. The output-force $\left(F_{\mathrm{o}}\right)$ of each muscle was calculated by the equation (Hildebrand \& Goslow, 2001):

$$
F_{\mathrm{o}}=F_{\mathrm{i}} \times m_{\mathrm{i}} / m_{\mathrm{o}}
$$

where $F_{\mathrm{i}}$ is the force of the muscle estimated from its PCSA, $m_{\mathrm{i}}$ is the in-lever moment arm, and $m_{\mathrm{o}}$ is the out-lever moment arm. Bite force was calculated as the sum of all the output-forces multiplied by 2 , considering both sides of the jaws and assuming bilateral symmetry (Huber \& Motta, 2004; Thomason, 1991). For comparisons with published data for other bird species, estimated bite forces were scaled to body mass. With the exception of the body mass measured for the specimens studied here, published body masses were used (Dunning, 2008).

\section{3 | RESULTS}

\section{1 | Description of the jaw musculature}

\subsection{1 | Depressor muscle}

M. depressor mandibulae ( $\mathrm{dm})$

This muscle has parallel fibers (Figure 2a) and a fleshy origin on the laterodorsal edge of the os exoccipitale, ventral to the crista nuchalis transversa (Figure 3a). The medial fibers are attached to a crest of the os exoccipitale not mentioned in previous osteological descriptions (Supporting Information Figure S3). The muscle spreads caudally to the cavum tympanicum and has a fleshy insertion on the fossa caudalis of the jaw (Figure 3h).

\subsection{2 | Adductor muscles}

M. adductor mandibulae externus superficialis (ames)

This is a triangle-shaped muscle that spreads dorsoventrally (Figure $2 b$, d). The muscle has a fleshy origin from the processus suprameaticus and a tendinous insertion on the processus zygomaticus (Figure $3 a, b)$. This tendon extends rostroventrally, and, before reaching the arcus jugalis level, forms a fan-shaped fleshy fiber arrangement that inserts via a wide attachment on the shallow and not conspicuous fossa lateralis mandibulae (Figure 3g).

\section{M. adductor mandibulae externus medialis}

This muscle was indistinguishable both anatomically and topologically from M. adductor mandibulae externus profundus (amep) and ames, as is typical of Neognathae (Holliday, 2009).

M. adductor mandibulae externus profundus (amep)

This muscle (Figure 2a,b,d) originates from a wide fleshy attachment that extends caudally, occupying the entire "temporal fossa 2" of Posso and Donatelli (2001) (Figure 3a,b, Supporting Information Figures S2 and S3). An aponeurosis that runs along the transversal crest of Posso and Donatelli (2001), subdividing the fossa temporalis, separates the amep from the M. pseudotemporalis superficialis (pss) muscle, located medially. The amep extends rostroventrally. On its medial aspect, it has a tendon that extends in the same direction and inserts on the processus coronoideus 1 of Posso and Donatelli (2001, i.e., the most rostrally positioned; Figure 3g).

\section{M. pseudotemporalis superficialis (pss)}

This muscle has a fleshy origin situated on the area muscularis aspera of the os laterosphenoidale, spreading caudomedially to the processus postorbitalis (Figures 2c and 3a,b). Its caudal limit is the transversal crest of the fossa temporalis. Crests 1 and 2 of Posso and Donatelli (2001) which delimit the area muscularis aspera form a slender projection, called "process of the caudal orbit" (Posso \& Donatelli, 2001; see Supporting Information). From this, an aponeurosis spreads rostroventrally along with the muscle and inserts via a tendon on the tuberculum pseudotemporale, ventral to the amp insertion and caudal to the amep insertion (Figure 3d).

M. pseudotemporalis profundus ( $p s p$ )

This muscle has an aponeurotic origin on the rostral portion of the processus orbitalis of the os quadratum (Figure 3f). This columnar muscle 


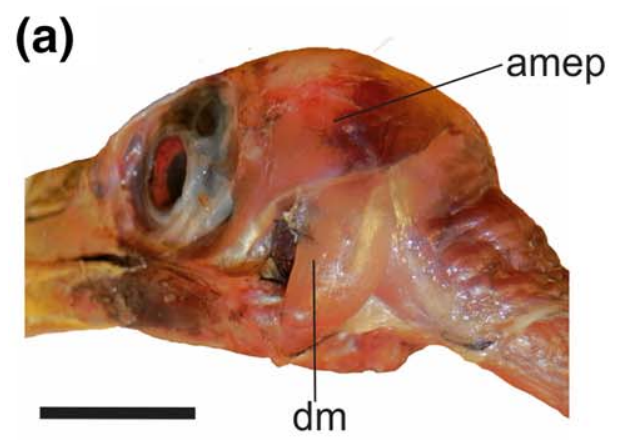

(b)
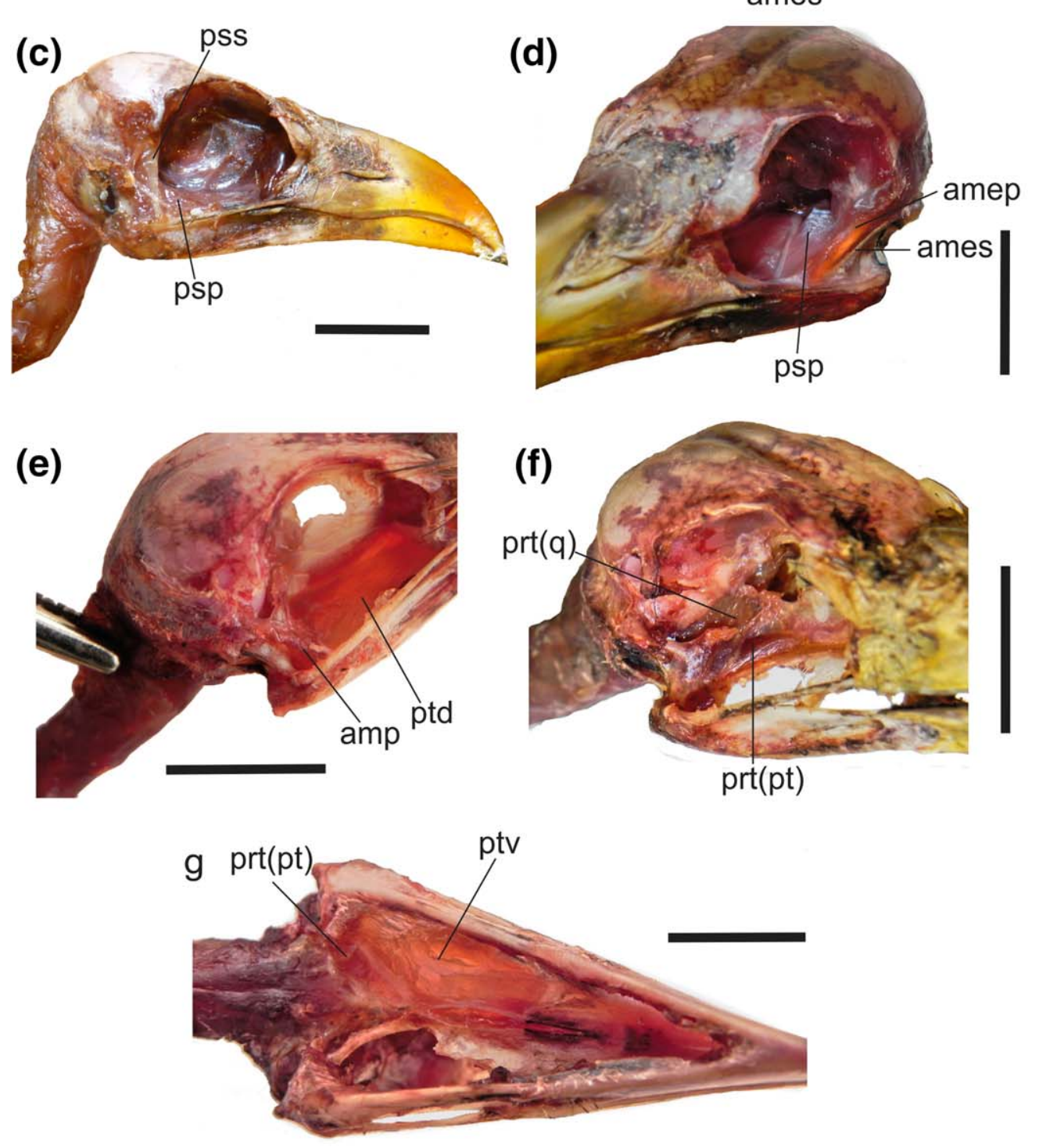

FIGURE 2 Jaw muscles of Guira guira in (a, b) left lateral views; (c) right lateral view; (d) left lateroposterior view; (e, f) right lateral views; (g) ventral view. Abbreviations: amep = M. adductor mandibulae externus profundus; ames = M. adductor mandibulae externus superficialis; $a m p=M$. adductor mandibulae posterior; $d m=M$. depressor mandibulae; $\operatorname{prt}(p t)=$. . protractor pars pterygoidei; $\operatorname{prt}(q)=M$. protractor pars quadrati; $p s p=$. pseudotemporalis profundus; $p s s=$. pseudotemporalis superficialis; $p t d=$. pterygoideus dorsalis; ptv = M. pterygoideus ventralis. Scale bar $=1 \mathrm{~cm}$

has a wide cross-section. It is rostroventrally projected and has a fleshy insertion on the medial aspect of the ramus mandibulae, without a conspicuous scar for the insertion site (Figure 2c,d). Some intra-specific variation regarding the extension of this insertion was observed in the studied specimens: it attaches anywhere on the surface between the processus coronoideus 1 and the most rostral limit of the fossa lateralis 

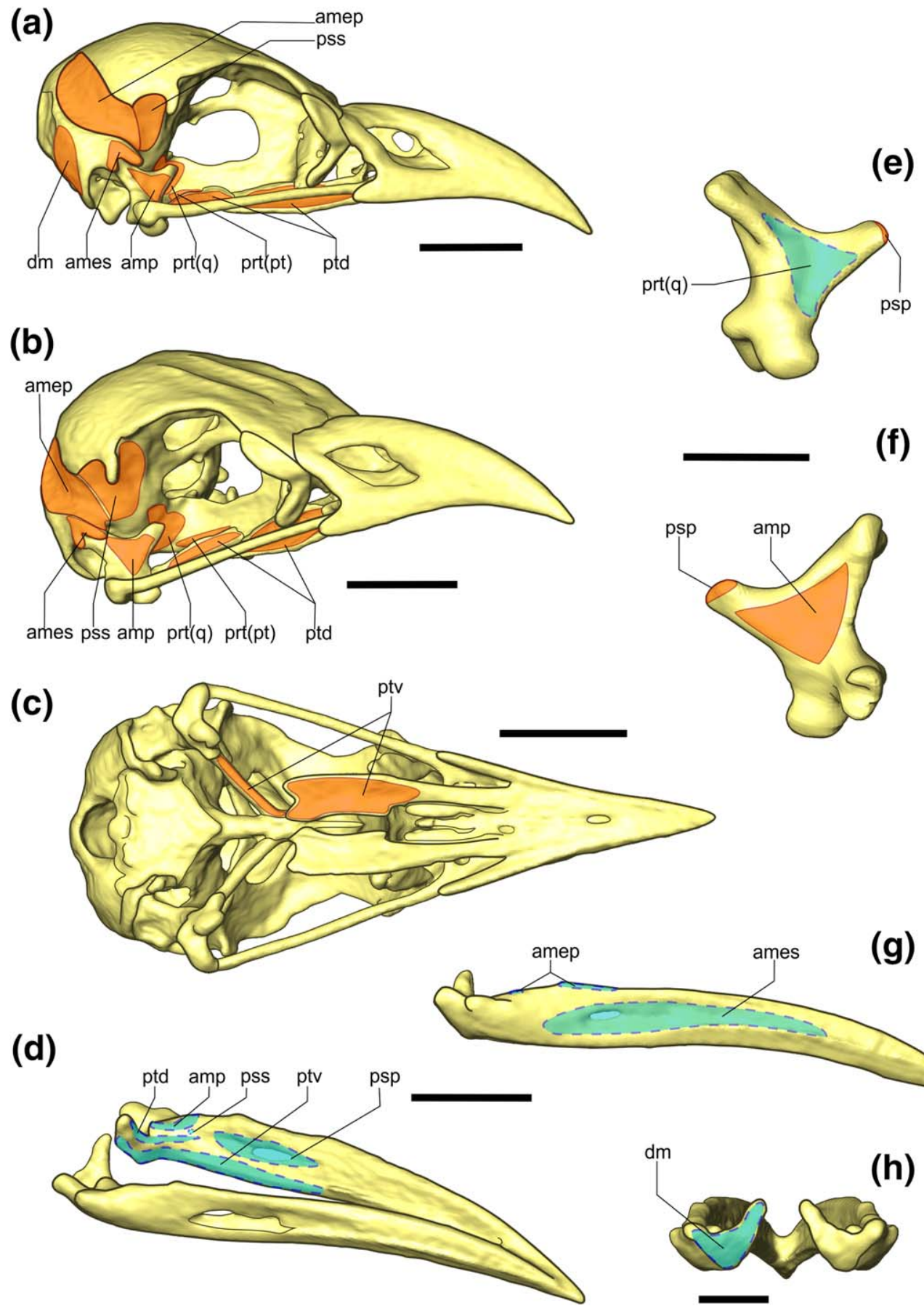

FIGURE 3 Three-dimensional model of Guira guira's skull showing origin and insertion sites of the muscles in the cranio-mandibular complex. Origin is indicated in the orange area (solid line), whereas the insertion is represented by the light blue area (dot line). (a) lateral view; (b) rostrolateral view and (c) ventral view; (d) laterodorsal view. Os quadratum of G. guira in (e) medial view and (f) lateral view. G. guira jaw in (g) lateral view and (h) caudal view. Abbreviations: amep $=$ M. adductor mandibulae externus profundus; ames = M. adductor mandibulae externus superficialis; $a m p=$. adductor mandibulae posterior; $d m=$. depressor mandibulae; $p r t(p t)=$ M. protractor pars pterygoidei; $\operatorname{prt}(q)=$ M. protractor pars quadrati; $p s p=$. pseudotemporalis profundus; $p s s=$. . pseudotemporalis superficialis; $p t d=$. pterygoideus dorsalis; $p t v=M$. pterygoideus ventralis. Three-dimensional models were constructed based on CTs. Scale bar in $(\mathrm{a}-\mathrm{d})$ and $(\mathrm{g})=1 \mathrm{~cm}$. Scale bar in $(\mathrm{e}, \mathrm{f})$ and $(\mathrm{h})=0.5 \mathrm{~cm}$

mandibulae. This insertion is located dorsal to the ptv insertion (Figure 3d).

\section{M. pterygoideus dorsalis (ptd)}

This is a long laminar muscle (Figure 2e). It originates from a wide, fleshy attachment that extends from the lateral side of the processus dorsalis of the os pterygoideum and occupies the entire dorsal surface of the pars lateralis of the os palatinum (Figure 3a,b). The ptd runs ventrocaudally and inserts on the caudomedial surface of the jaw, below the fossa articularis quadratica, through an aponeurosis (Figure 3d). The caudal limit of this insertion is the rostral surface of the processus mandibulae medialis, extending rostrally to the processus coronoideus 2 . 


\section{M. pterygoideus ventralis (ptv)}

The $p t v$ is a laminar muscle (Figure $2 \mathrm{~g}$ ) with a wide, fleshy origin on the entire surface of the long and deep fossa ventralis of the os palatinum (Figure 3c) and on the ventral surface of the os pterygoideum. There is also a variably developed aponeurosis attached to the processus accesorius (Zusi, \& Livezey, 2006). The ptv projects caudoventrally and inserts on the medioventral surface of the ramus mandibulae. This insertion is fleshy and extends caudally to the processus medialis mandibulae and rostrally to the level of the processus coronoideus 1 (Figure 3d), representing the most ventral insertion of the muscular mandibular system. No scars of this insertion are present on the jaw.

\section{M. adductor mandibulae posterior ( $\mathrm{amp}$ )}

It has a fleshy origin located on the lateral surface of the corpus of the os quadratum (Figure $3 \mathrm{f}$ ). Its caudal limit is situated on the lateral surface of the processus oticus, while the rostral one is on the ventrolateral surface of the processus orbitalis. This muscle is short and stout and projects ventrolaterally (Figure 2e). Its fleshy insertion is located on the medial surface of the ramus mandibulae, in front of the fossa articularis quadratica, ventrocaudal to the processus coronoideus 2 and dorsal to both $p t$ and pss insertions (Figure 3d).

\subsection{3 | Protractor muscle}

\section{M. protractor pterygoidei et quadrati (prt)}

This is a stout and short muscle with two bellies (Figure $2 \mathrm{f}, \mathrm{g}$ ). The more robust one originates on the angle formed between the os laterosphenoidale and the septum interorbitale, ventral to the area muscularis aspera and ventrocaudal to the fonticuli orbitalis, and inserts on the medial surface of the corpus ossa quadrati with its caudal limit on the base of the processus orbitalis (Figure 3e). The second belly is wider and shorter, with its origin situated rostroventrally to the former and with its insertion located on the medial surface of the processus dorsalis of the os pterygoideum (Figure 3a,b).

\section{2 | Biomechanical modelling, PCSA, and bite force}

Mean muscle masses $(M)$, averaged fiber lengths (FL), average angles of pinnation $(A)$, input-forces $\left(F_{i}\right)$, output-forces $\left(F_{0}\right)$, PCSA, and MA of each muscle are summarized in Table 1.

Total average jaw muscle mass was $0.914 \mathrm{~g}$, which represents $0.65 \%$ of mean body mass. PCSA values ranged from $2.676 \mathrm{~mm}^{2}$ for the amp to $24.326 \mathrm{~mm}^{2}$ for the ptd. The ptd $(6.082 \mathrm{~N})$ and ames $(6.074 \mathrm{~N})$ input-force were the highest, almost double that of the pss (the third strongest muscle). Estimated bite force for Guira guira was $6.676 \mathrm{~N}$, while standardized bite force (BF/BM) was $0.047 \mathrm{~N} / \mathrm{g}$ (Table 2).

The $d m$ presented the lowest value of MA (0.05), indicating a relatively greater functional specialization for velocity, whereas the highest MA were for psp (0.284) and for ames (0.205), indicating a relatively greater capacity for force prior to velocity.

\section{I DISCUSSION}

\subsection{J Jaw muscle anatomy, functional morphology, and force-generating capacity}

This study represents the first detailed myological description published for Guira guira and the order Cuculiformes. Marceliano (1996) in her unpublished thesis describes the jaw muscle anatomy of this and another cuculiform, Coccyzus americanus Linnaeus 1758, but her description is in the context of a comparative analysis of the jaw musculature of Opisthocomus hoazin Müller 1776 and is not specific to Cuculiformes. Our study of the jaw muscles of G. guira indicates that this taxon's musculature does not present obvious differences from the typical bauplan of Neognathae (see Holliday \& Witmer, 2007; Vanden Berge \& Zweers, 1993): there are no losses, gains, or new configurations of jaw muscles. Marceliano (1996) states that the m. protractor pterigoidei et quadrati (pars pterigoidei) (prt(pt)) muscle is absent in this species, but in the present study it was possible to distinguish this muscle in all the specimens dissected. There are also differences in some origin and insertion features described by Marceliano (1996); for example, she affirms that the $\mathrm{m}$. depressor mandibulae $(\mathrm{dm})$ has two bellies but we could identify only one in all the specimens dissected.

Despite the apparently unspecialized cranio-mandibular complex of G. guira, certain features of the individual muscles can be related to its trophic habit. Cuculiformes feed using their beak tip to pluck prey which is then processed mechanically at the base of the bill (Korzun et al., 2003). Catching living prey requires quick movements. In birds, the opening of the beak is performed by two muscles (Bhattacharyya, 2013; Bock, 1964): the $d m$ and the $m$. protractor pterygoidei et quadrati (prt). In the G. guira jaw muscle system, the $d m$ has one of the highest values of muscle mass, while prt is a small muscle. Nevertheless, the PCSA value for the $d m$ is among the lowest values of the system (Table 1). The parallel fibers of the $d m$ and its low MA values suggest its purpose could be to produce a rapid opening of the jaw. The static morphofunctional analysis presented by Korzun et al. (2003), which was restricted to Cuculus canorus, does not include PCSA or MA values, so there are no available data to compare with our results.

Closing of the beak is carried out by the adductor muscle complex (Bhattacharyya, 2013; Holliday \& Witmer, 2007; Van der Meij \& Bout, 2004). Reilly, McBrayer and White (2001) discriminated the main function of each adductor group in amniotes according to their position within the complex. The internal group usually runs from the anterior palate to the back of the lower jaw. This means that, when the jaw is depressed, this muscle group is positioned perpendicular to it, producing both rapid and powerful jaw closing. The external adductor muscles extend from the side of the skull down to the back of the lower jaw and are at their most perpendicular orientation to the jaw when it is closed, so they are more effective at applying static pressure on a food item already placed in the jaw. Because the main muscles of these two groups in birds are the pterygoids and the adductor mandibulae externus, they can be placed within the context of the functional scheme of Reilly et al. (2001). In agreement with this previous work, in G. guira, both pterygoid muscles present lower MA values indicating that they 
TABLE 2 Compared bite force (BF), body mass (BM), and standardized bite force (BF/BM) of Guira guira compared with selected bird species from published data

\begin{tabular}{|c|c|c|c|c|c|c|}
\hline Taxa & Order & $\mathrm{BF}(\mathrm{N})$ & $\mathrm{BM}(\mathrm{g})$ & $\mathrm{BF} / \mathrm{BM}$ & Trophic habit & Source \\
\hline Rhea americana & Rheiformes & $30.10^{\mathrm{b}}$ & 12500.0 & 0.002 & o & Degrange et al. (2010) \\
\hline Accipiter cooperii & Accipitriformes & $3.90^{\mathrm{a}}$ & 342.7 & 0.011 & z & Sustaita (2008) \\
\hline Cariama cristata & Gruiformes & $19.42^{\mathrm{b}}$ & 1500.0 & 0.013 & z & Degrange et al. (2010) \\
\hline Zenaida macroura & Columbiformes & $1.58^{\mathrm{b}}$ & 119.0 & 0.013 & g & Corbin et al. (2014) \\
\hline Chunga burmeisteri & Gruiformes & $19.42^{\mathrm{b}}$ & 1300.0 & 0.015 & $z$ & Degrange et al. (2010) \\
\hline Geranoaetus melanoleucus & Falconiformes & $50.00^{b}$ & 3100.0 & 0.016 & z & Degrange et al. (2010) \\
\hline Sarcoramphus papa & Ciconiiformes & $69.00^{b}$ & 3375.0 & 0.020 & $z$ & Degrange et al. (2010) \\
\hline Accipiter striatus & Accipitriformes & $2.73^{\mathrm{a}}$ & 113.5 & 0.024 & z & Sustaita (2008) \\
\hline Falco peregrinus & Falconiformes & $16,90^{\mathrm{a}}$ & 683.6 & 0.025 & $z$ & Sustaita (2008) \\
\hline Falco mexicanus & Falconiformes & $16.50^{\mathrm{a}}$ & 487.7 & 0.034 & z & Sustaita (2008) \\
\hline Falco columbarius & Falconiformes & $5.26^{\mathrm{a}}$ & 137.0 & 0.038 & $z$ & Sustaita (2008) \\
\hline Falco sparverius & Falconiformes & $3.50^{\mathrm{a}}$ & 78.8 & 0.044 & z & Sustaita (2008) \\
\hline Guira guira & Cuculiformes & $6.68^{a}$ & 141.0 & 0.047 & $z$ & Present work \\
\hline Dendroica coronata & Passeriformes & $0.67^{\mathrm{b}}$ & 11.8 & 0.057 & i/o & Corbin et al. (2014) \\
\hline Melanerpes carolinus & Piciformes & $4.78^{b}$ & 69.6 & 0.680 & $i / o$ & Corbin et al. (2014) \\
\hline Cyanocitta cristata & Passeriformes & $6.3^{\mathrm{b}}$ & 88.0 & 0.072 & o & Corbin et al. (2014) \\
\hline Tyrannus forficatus & Passeriformes & $3.46^{\mathrm{b}}$ & 39.3 & 0.088 & $i / f$ & Corbin et al. (2014) \\
\hline Picoides pubescens & Piciformes & $2.23^{\mathrm{b}}$ & 25.06 & 0.089 & $i / f$ & Corbin et al. (2014) \\
\hline Myiopsitta monachus & Psittaciformes & $16.74^{\mathrm{a}}$ & 120.0 & 0.140 & g & Carril et al. (2015) \\
\hline Passer domesticus & Passeriformes & $5.49^{b}$ & 27.7 & 0.198 & g & Corbin et al. (2014) \\
\hline Certhidea olivacea & Passeriformes & $2.0^{\mathrm{a}}$ & 9.88 & 0.202 & $\mathrm{i}$ & Soons et al. (2015) \\
\hline Carduelis flammea & Passeriformes & $2.9^{\mathrm{b}}$ & 12.6 & 0.230 & o & Van der Meij and Bout $(2006,2008)$ \\
\hline Serinus mozambiques & Passeriformes & $2.9^{\mathrm{b}}$ & 11.95 & 0.243 & g & Van der Meij and Bout $(2006,2008)$ \\
\hline Lonchura punctata & Passeriformes & $3.7^{\mathrm{b}}$ & 13.6 & 0.272 & g & Van der Meij and Bout $(2006,2008)$ \\
\hline Lonchura oryzivora & Passeriformes & $9.60^{\mathrm{b}}$ & 30.4 & 0.315 & g & Van der Meij and Bout (2004) \\
\hline Geospiza scadens & Passeriformes & $8.90^{\mathrm{a}}$ & 22.7 & 0.392 & g & Soons et al. (2015) \\
\hline Geospiza fuliginosa & Passeriformes & $7.10^{\mathrm{a}}$ & 14.5 & 0.490 & g & Soons et al. (2015) \\
\hline Cardinalis cardinalis & Passeriformes & $22.9^{\mathrm{b}}$ & 42.65 & 0.537 & o & Corbin et al. (2014) \\
\hline Mycerobas affinis & Passeriformes & $38.40^{\mathrm{b}}$ & 70.0 & 0.549 & g & Van der Meij and Bout (2004) \\
\hline Geospiza fortis & Passeriformes & $30.40^{\mathrm{a}}$ & 24.00 & 1.267 & g & Soons et al. (2015) \\
\hline Geospiza magnirostris & Passeriformes & $57.9^{\mathrm{a}}$ & 32.77 & 1.767 & g & Soons et al. (2015) \\
\hline Geospiza magnirostris & Passeriformes & $70.77^{b}$ & 32.77 & 2.160 & g & Herrel et al. (2005) \\
\hline
\end{tabular}

The data is arranged by standardized bite force in increasing order.

Abbreviations: $\mathrm{f}=$ frugivore; $\mathrm{g}=$ granivore; $\mathrm{i}=$ insectivore; $\mathrm{o}=$ omnivore; $\mathrm{z}=$ zoophagous.

${ }^{a}$ Estimated bite force from PCSA.

${ }^{\mathrm{b}}$ Measured bite force using a force transducer.

prioritize velocity over force, contributing to the capture of agile prey, while they also retract the kinetic system (e.g., Bhattacharyya, 2013). Conversely, the group of external adductor muscles (ames and amep) exhibit high values of MA indicating that these muscles prioritize force. The psp was the muscle with the highest MA as a result of its distal insertion relative to the fulcrum within the adductor chamber, which increases its in-lever arm. Furthermore, it is a vertically oriented muscle with a parallel fiber arrangement. All these features indicate a greater force-generating capacity, which could be related to diminution of protraction of the upper jaw while food is in the bill. Compared to the 
external adductor muscles, $p s p$ does not contract isometrically, and this requires an excessive use of energy (Bock, 1999). Therefore, its highest MA value could be more related to this energy budget, rather than the maximum force capacity of the muscle.

\section{2 | Bite force}

Bite force has a strong influence on feeding strategies in that a zoophagous species should be able to discern which prey items it is capable of killing by biting (Herrel et al., 2005; Van der Meij \& Bout, 2004, 2006) and which ones will require a different strategy (e.g., the use of its hind limbs).

It has been already stated that only few bite force have been published data for birds and those are highly biased toward Passeriformes (Carril et al. 2015; Corbin et al., 2014; Degrange, Tambussi, Moreno, Witmer, \& Wroe, 2010; Herrel et al. 2002, 2005, 2009; Santana et al., 2010; Soons et al., 2015; Sustaita, 2008; Van der Meij \& Bout, 2004, 2006). Although these data are useful for a general comparison, definitive inferences should not be drawn from this limited information, especially given that bite forces were obtained by different methods and in different orders. Nonetheless, estimating bite force by the PCSA method has been proven to be an appropriate proxy of the real bite force (Santana et al., 2010; Sustaita \& Hertel, 2010).

As listed in Table 2, zoophagous birds have the lowest values of standardized bite force, while the granivorous have the highest values. This concurs with previous studies that demonstrate that larger bite forces are needed for the processing and husking of seeds (Herrel et al., 2005; Van der Meij \& Bout, 2006, 2008). Among zoophagous birds, G. guira presents the highest standardized bite force. However, these results should be interpreted with caution: (a) bite force estimates of predatory birds such as Falconiformes and Accipitriformes were made only for the beak tip (Sustaita, 2008), but the estimation for G. guira was calculated for the base of the beak (i.e., the decrease of the out-lever moment arm increases the force exerted on the food item), and (b) the diet composition and mechanism of food processing of G. guira are different than Falconiformes, Accipitriformes, and Gruiformes which prey mostly on vertebrates and process them by tearing off pieces with the tip of the beak before swallowing (Sustaita, 2008; Sustaita \& Hertel, 2010). Guira guira has a diet mainly composed of insects, which it processes in a more caudal location in the beak (Korzun et al., 2003; Payne, 1997). Omnivorous birds have a less defined position within the table, which could be related to the wider range of trophic items, varying in size and hardness, in their diets. Using a functional ecological classification of organisms that takes into account the material properties of their prey items could be a better approach to analyzing the relationship between cranio-mandibular complex morphology, bite force, and feeding ecology than focusing on traditional dietary categories (Santana et al., 2010). For example, in the current classification, it might be expected that Zenaida macroura would have a higher standardized BF because it is a granivore. However, this does not take into account the fact that this species feeds on smaller and probably softer seeds than finches which have the highest BF/BM values.

\section{3 | Dietary implications}

Guira guira is reported as the southern-most ranging cuculid with the broadest diet in terms of size and variety of food items ingested (Beltzer, 1995; Repenning et al. 2009). The literature classifies G. guira as a zoophagous bird (Beltzer, 1995; Bernal de Pereyra, 1927, 1935; Coutinho et al. 2014; Daguerre, 1922; Koski \& Merçon, 2015; Morais et al. 2013; Payne, 1997; Repenning et al. 2009) among which it is occasionally characterized as an exclusively insectivorous species (Goijman \& Zaccagnini, 2008; Legrand, 1934; Leveau \& Leveau, 2004). Occasional consumption of large vertebrate prey by the species is likely mediated by food processing prior to swallowing, widening the range of potential prey size and type (Herrel, Damme, Vanhooydonck, \& Vree, 2001; Hespenheide, 1966; Korzun, Erard, \& Gasc, 2004; Korzun et al., 2003; Van der Meij \& Bout, 2006).

With respect to the feeding strategy, this species is an active forager that usually feeds in a flock of a few individuals. Field observations and stomach content analyses indicate that this species prefers smaller and more abundant prey whenever available, likely because their capture demands a lower energy expenditure. But during seasons when standard food is limited, G. guira has been reported to ingest larger prey (Beltzer, 1995; Martins \& Donatelli, 2001), an action probably facilitated by the structural and biomechanical features of its jaw musculature. This opportunistic diet shift of the Guira cuckoo underlines its dietary versatility and ability to effectively use available food resources.

\section{5 | CONCLUSIONS}

We recognize a velocity component and a force component in the jaw muscles of the Guira cuckoo. The external adductor muscles prioritize force, as shown by their high values of mass and MA and their perpendicular orientation when the beak is closed. The $d m$ and the internal adductor group (mainly $p t$ ) prioritize velocity, based on their relatively high muscle masses and low MA values. The ecological value of these traits in the form-function complex (Bock \& von Wahlert, 1965) is related to (a) performing a fast capture of agile living prey and (b) widening the range of prey size when processing the food item. The morphological observations are in accordance with the versatility of Guira guira and its capability to thrive in different habitats, including urban areas.

\section{ACKNOWLEDGMENTS}

The authors thank two reviewers and the editor, Matthias Starck, for helpful comments and suggestions. The authors are also grateful to Rustán family who donated specimens to the project. Catherine Early and Tomas Leake are thanked for improving our English. We are indebted to CONICET for its permanent support. This is a contribution of the projects PICT2014-2330, PIP2014-0059 to CPT and PUE-2016 to CICTERRA.

\section{CONFLICT OF INTEREST}

The authors have no conflict of interest to declare. 


\section{AUTHOR CONTRIBUTIONS}

FJD and CPT conceived the ideas and designed methodology; SP, MMDF and GAT collected the data; SP, FJD and CPT analyzed the data; SP led the writing of the manuscript. All authors contributed critically to the drafts and gave final approval for publication.

\section{ORCID}

Sofía Pestoni (D) http://orcid.org/0000-0001-9280-090X

\section{REFERENCES}

Bannerman, D. A. (1933). The birds of tropical West Africa, with special reference to those of Gambia, Sierra Leone, the Gold Coast and Nigeria. London, UK: Crown Agents for the Colonies Publishers.

Baumel, J., \& Witmer, L. (1993). Osteology. In J. J. Baumel, A. S. King, J. E. Breazile, \& H. E. Evans (Eds.), Handbook of avian anatomy: Nomina anatomica avium (pp. 45-132). Cambridge, MA: Cambridge University Press.

Beddard, F. E. (1885). Notes on the visceral anatomy of birds. No. 1. On the so-called Omentum. Proceedings of Zoolological Society of London, 53, 833-844.

Beltzer, A. H. (1995). Biología alimentaria del Pirincho Guira guira (Aves: Cuculidae) en el valle alluvial del río Paraná Medio, Argentina. Revista de Ecología Latinoamericana, 2, 13-18.

Berger, A. J. (1952). The comparative functional morphology of the pelvic appendage in three genera of Cuculidae. American Midland Naturalist, 47(3), 513-605.

Berger, A. J. (1960). Some anatomical characters of the Cuculidae and the Musophagidae. Wilson Bulletin, 72, 60-140.

Bernal de Pereyra, C. (1927). Observaciones sobre algunas aves de Zelaya (Prov. de Buenos Aires). El Hornero, 4, 75-77.

Bernal de Pereyra, C. (1935). Sobre la nidificación de algunas aves. El Hornero, 6, 102-104.

Bhattacharyya, B. N. (2013). Avian jaw function: Adaptation of the seven-muscle system and a review. Proceedings of the Zoological Society, 66(2), 75-85.

Bock, W. J. (1964). Kinetics of the avian skull. Journal of Morphology, 114 (1), 1-42.

Bock, W. J. (1974). The avian skeletomuscular system. Avian Biology, 4, 119-257.

Bock, W. J. (1999). Cranial kinesis revisited. Zoologischer Anzeiger, 238, 27-40.

Bock, W. J., \& von Wahlert, G. (1965). Adaptation and the FormFunction complex. Evolution, 19, 269-299.

Briggs, D. E. G. (2005). Seilacher on the science of form and function. In D. E. G. Briggs (Ed.), Evolving form and function: Fossils and development. Proceedings of a symposium honoring Adolf Seilacher for his contributions to paleontology, in celebration of his 80th birthday (pp. 324). New Haven, CT: Yale Peabody Museum of Natural History.

Buzug, T. M. (2008). Computed tomography: From photon statistics to modern cone-beam CT. Berlin, Germany: Springer Science \& Business Media.

Carril, J., Degrange, F. J., \& Tambussi, C. P. (2015). Jaw myology and bite force of the monk parakeet (Aves, Psittaciformes). Journal of Anatomy, 227(1), 34-44.

Clabaut, C., Herrel, A., Sanger, T., Smith, T., \& Abzhanov, A. (2009). Development of beak polymorphism in the African seedcracker, Pyrenestes ostrinus. Evolution \& Development, 11(6), 636-646.
Corbin, C. E., Lowenberger, L. K., \& Gray, B. L. (2014). Linkage and trade-off in trophic morphology and behavioural performance of birds. Functional Ecology, 29, 808-815.

Coutinho, A. G., Serra, K. S., Junior, L. G. S., \& Lima, D. C. (2014). Predation of Green iguana (Iguana iguana) by Guira cuckoo (Guira guira) in northeastern Brazil. Brazilian. Journal of Ornithology, 22, 305-306.

Daguerre, J. B. (1922). Lista de aves coleccionadas y observadas en Rosas, F.C.S. El Hornero, 2, 259-271.

De la Peña, M. R. (2016). Aves Argentinas: Descripción, comportamiento, reproducción y distribución. Charadriidae a Trochilidae. Comunicaciones Museo Provincial de Ciencias Naturales Florentino Ameghino, 21, 1-633.

Degrange, F. J., Tambussi, C. P., Moreno, K., Witmer, L. M., \& Wroe, S. (2010). Mechanical analysis of feeding behavior in the extinct "terror bird" Andalgalornis steulleti (Gruiformes: Phorusrhacidae). PLoS One, 5 (8), e11856.

Dunning, J. (2008). CRC handbook of avian body masses (2nd ed.). Boca Raton, FL: CRC Press/Taylor \& Francis Group.

Gans, C. (1982). Fiber architecture and muscle function. Exercise and Sport Sciences Reviews, 10, 160-207.

Goijman, A. P., \& Zaccagnini, M. E. (2008). The effects of habitat heterogeneity on avian density and richness in soybean fields in Entre Ríos, Argentina. El Hornero, 23, 67-76.

Herrel, A., Damme, R. V., Vanhooydonck, B., \& Vree, F. D. (2001). The implications of bite performance for diet in two species of lacertid lizards. Canadian Journal of Zoology, 79, 662-670.

Herrel, A., O'Reilly, J. C., \& Richmond, A. M. (2002). Evolution of bite performance in turtles. Journal of Evolutionary Biology, 15, 1083-1094.

Herrel, A., Podos, J., Huber, S. K., \& Hendry, A. P. (2005). Bite performance and morphology in a population of Darwin's finches: Implications for the evolution of beak shape. Functional Ecology, 19, 43-48.

Herrel, A., Podos, J., Vanhooydonck, B., \& Hendry, A. P. (2009). Forcevelocity trade-off in Darwin's finch jaw function: A biomechanical basis for ecological speciation? Functional Ecology, 23(1), 119-125.

Hespenheide, H. A. (1966). The selection of seed size by finches. Wilson Bulletin, 78, 191-197.

Hildebrand, M., \& Goslow, G. (2001). Analysis of vertebrate structure. New York: Wiley.

Holliday, C. M. (2009). New insights into dinosaur jaw muscle anatomy. Anatomical Record, 292(9), 1246-1265.

Holliday, C. M., \& Witmer, L. M. (2007). Archosaur adductor chamber evolution: Integration of musculoskeletal and topological criteria in jaw muscle homology. Journal of Morphology, 268, 457-484.

Huber, D. R., \& Motta, P. J. (2004). Comparative analysis of methods for determining bite force in the spiny dogfish Squalus acanthias. Journal of Experimental Zoology Part A Comparative Experimental Biology, 301, 26-37.

Hughes, J. M. (2000). Monophyly and phylogeny of cuckoos (Aves, Cuculidae) inferred from osteological characters. Zoological Journal of the Linnean Society, 130(2), 263-307.

Kaufman, K. R., An, K. N., Litchy, W. J., \& Chao, E. Y. S. (1991). Physiological prediction of muscle forces-I. Theoretical formulation. Neuroscience, 40, 781-792.

Korzun, L. P., Erard, C., \& Gasc, J.-P. (2001). Les particularités morphofonctionnelles des appareils du bec et hyoidien chez les touracos (Aves, Musophagidae): Relations avec la frugivorie. Life Sciences, 324 (11), 965-977.

Korzun, L. P., Erard, C., \& Gasc, J. P. (2004). Morphofunctional study of the bill and hyoid apparatus of Momotus momota (Aves, 
Coraciiformes, Momotidae): Implications for omnivorous feeding adaptation in motmots. Comptes Rendus Biologies, 327, 319-333.

Korzun, L. P., Erard, C., Gasc, J.-P., \& Dzerzhinsky, F. J. (2003). Biomechanical features of the bill and jaw apparatus of cuckoos, turacos and the hoatzin in relation to food acquisition and processing. Ostrich, 74(1-2), 48-57.

Korzun, L. P., Erard, C., Gasc, J., \& Dzerzhinsky, F. J. (2008). Bill and hyoid apparatus of pigeons (Columbidae) and sandgrouse (Pteroclididae): A common adaptation to vegetarian feeding? Comptes Rendus Biologies, 331, 64-87.

Koski, D. A., \& Merçon, L. (2015). Predation on Tropidurus torquatus (Squamata: Tropiduridae) by the Guira Cuckoo Guira guira (Aves: Cuculiformes) in the state of Espírito Santo, Southeastern Brazil. Herpetological Notes, 8, 35-37.

Legrand, D. (1934). La propagación de árboles por aves. El Hornero, 5, 35-37.

Leveau, L. M., \& Leveau, C. M. (2004). Comunidades de aves en un gradiente urbano de la ciudad de Mar del Plata. El Hornero, 19, 13-21.

Lieber, R. (2002). Skeletal muscle structure, function, and plasticity: The physiological basis of rehabilitation. Philadelphia, PA: Lippincott Williams and Wilkins.

Lowe, P. R. (1943). Some notes on the anatomical differences obtaining between the Cuculiae and the Musophagidae, with special reference to the specialization of the esophagus in Cuculus canorus Linnaeus. lbis, 85(4), 490-515.

Marceliano, M. L. V. (1996). Estudo osteológico e miológico do crânio de Opisthocomus hoazin (Muller, 1776) (Aves: Opisthocomidae) comparado com algumas espécies de Cracidae, Musophagidae e Cuculidae. Boletin Museo Para. Emílio Goeldi, 12, 95-246.

Martins, F. D. C., \& Donatelli, R. J. (2001). Estratégia alimentar de Guira guira (Cuculidae, Crotophaginae) na região centro-oeste do Estado de São Paulo. Ararajuba, 9, 89-94.

Mayr, G., Manegold, A., \& Johansson, U. S. (2003). Monophyletic groups within "higher land birds" - Comparison of morphological and molecular data. Journal of Zoological Systematics and Evolutionary Research, 41, 233-248.

Morais, A. R., Siqueira, M. N., \& Bastos, R. P. (2013). Predation on a Neotropical treefrog (Scinax aff. fuscovarius) by Guira guira (Aves, Cuculidae) in the state of Goiás, Central Brazil. Herpetological Notes, 6, 567-568.

Payne, R. B. (1997). Order Cuculiformes. In J. del Hoyo, A. Elliot, \& J. Sargatal (Eds.), Handbook of birds of the world. Sandgrouse to cuckoos (Vol. 4, pp. 480-607). Barcelona, Spain: Lynx.

Pennycuick, C. J. (1996). Stress and strain in the flight muscles as constraints on the evolution of flying animals. Journal of Biomechanics, 29(5), 577-581.

Posso, S. R., \& Donatelli, R. J. (2001). Cranial osteology and systematic implications in Crotophaginae (Aves, Cuculidae). Journal of Zoological Systematics and Evolutionary Research, 39, 247-256.

Posso, S. R., \& Donatelli, R. J. (2005). Skull and mandible formation in the cuckoo (Aves, Cuculidae): Contributions to the nomenclature in avian osteology and systematics. European Journal of Morphology, 42, 163-172.

Prum, R. O., Berv, J. S., Dornburg, A., Field, D. J., Townsend, J. P., Lemmon, E. M., \& Lemmon, A. R. (2015). A comprehensive phylogeny of birds (Aves) using targeted next-generation DNA sequencing. Nature, 526(7574), 569-573.

Pycraft, W. P. (1903). Contributions to the osteology of birds. Part VI, Cuculiformes. Proceedings of the Royal Society of London, 1, 258291.
Reilly, S. M., McBrayer, L. D., \& White, T. D. (2001). Prey processing in amniotes: Biomechanical and behavioral patterns of food reduction. Comparative Biochemistry and Physiology A, 128, 397-415.

Reiser, P. J., Welch, K. C. J., Suarez, R. K., \& Altshuler, D. L. (2013). Very low force generating ability and unusually high temperature dependency in hummingbird flight muscle fibers. Journal of Experimental Biology, 216, 2247-2256.

Repenning, M., Basso, H. C. P., Rossoni, J. R., Krügel, M. M., \& Fontana, C. S. (2009). Análise comparativa da dieta de quatro espécies de cucos (Aves: Cuculidae), no sul do Brasil. Zoologia (Curitiba, Impresso), $26,443-453$.

Ritchie, J. M. (1954). The relation between force and velocity of shortening in rat muscle. The Journal of Physiology, 123(3), 633-639.

Santana, S., Dumont, E. R., \& Davis, J. L. (2010). Mechanics of bite force production and its relationship to diet in bats. Functional Ecology, 24, 776-784.

Schneider, C. A., Rasband, W. S., \& Eliceiri, K. W. (2012). NIH image to ImageJ: 25 years of image analysis. Nature Methods, 9(7), 671-675.

Seilacher, A. (1991). Self-organizing mechanisms in morphogenesis and evolution. In N. Schmidt-Kittler \& K. Vogel (Eds.), Constructional morphology and evolution (pp. 252-270). Berlin, Germany: SpringerVerlag.

Shufeldt, R. W. (1901). The osteology of the cuckoos. Proceedings of the American Philosophy Society, 19, 4-51.

Sibley, C. G., \& Ahlquist, J. E. (1990). Phylogeny and classification of birds: A study in molecular evolution. New Haven, CT: Yale University Press.

Soons, J., Genbrugge, A., Podos, J., Adriaens, D., Aerts, P., Dirckx, J., \& Herrel, A. (2015). Is beak morphology in Darwin's Finches tuned to loading demands? PLoS One, 10(6), e0129479.

Sustaita, D. (2008). Musculoskeletal underpinnings to differences in killing behavior between North American Accipiters (Falconiformes: Accipitridae) and Falcons (Falconidae). Journal of Morphology, 269(3), 283-301.

Sustaita, D., \& Hertel, F. (2010). In vivo bite and grip forces, morphology and prey-killing behavior of North American accipiters (Accipitridae) and falcons (Falconidae). Journal of Experimental Biology, 213, 26172628.

Thomason, J. J. (1991). Cranial strength in relation to estimated biting forces in some mammals. Canadian Journal of Zoology, 69(9), 23262333.

van der Meij, M. A. A., \& Bout, R. G. (2004). Scaling of jaw muscle size and maximal bite force in finches. The Journal of Experimental Biology, 207(Pt. 16), 2745-2753.

van der Meij, M. A. A., \& Bout, R. G. (2006). Seed husking time and maximal bite forces in finches. Journal of Experimental Biology, 209, 3329-3335.

van der Meij, M. A. A., \& Bout, R. G. (2008). The relationship between shape of the skull and bite force in finches. Journal of Experimental Biology, 211, 1668-1680.

Vanden Berge, J. C., \& Zweers, G. A. (1993). Myologia. In J. Baumel, A King, J. E. Breazile, \& H. Evans (Eds.), Handbook of avian anatomy: Nomina anatomica avium (pp. 189-247). Cambridge, MA: Cambridge University Press.

Verheyen, R. (1956). Contribution a l'anatomie et a la systématique de touracos (Musophagi) et des coucous (Cuculiformes). Bulletin de L'Institut Royal des Sciences Naturelles de Belgique, 32, 17-28.

Vizcaíno, S. F., de luliis, G., \& Bargo, M. S. (1998). Skull shape, masticatory apparatus and diet of Vassallia and Holmesina (Mammalia: 
Xenarthra: Pampatheriidae). When anatomy constrains destiny. Journal of Mammal Evololuton, 5, 291-322.

Vogel, S. (2013). Comparative biomechanics: Life's physical world (2nd ed.). Princeton, NJ: Princeton University Press.

Witmer, L. M., \& Rose, K. D. (1991). Biomechanics of the jaw apparatus of the gigantic Eocene bird Diatryma: Implications for diet and mode of life. Paleobiology, 17(02), 95-120.

Zinoviev, A. V. (2007). Apparatus of bipedal locomotion of Cuculiforms (Aves, Cuculiformes): Scenario of an adaptive evolution. Zoologichesky Zhurnal, 86, 1-9.

Zusi, R. L., \& Livezey, B. C. (2006). Variation in the os palatinum and its structural relation to the palatum osseum of birds (Aves). Annals of Carnegie Museum, 75, 137-180.

\section{SUPPORTING INFORMATION}

Additional Supporting Information may be found online in the supporting information tab for this article.

How to cite this article: Pestoni S, Degrange FJ, Tambussi CP, Demmel Ferreira MM, Tirao GA. Functional morphology of the cranio-mandibular complex of the Guira cuckoo (Aves). Journal of Morphology. 2018;279:780-791. https://doi.org/10.1002/ jmor.20810 